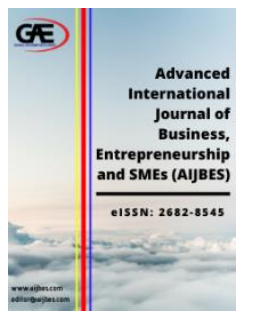

\author{
ADVANCED INTERNATIONAL JOURNAL OF \\ BUSINESS, ENTREPRENEURSHIP AND SMES \\ (AIJBES) \\ www.aijbes.com
}

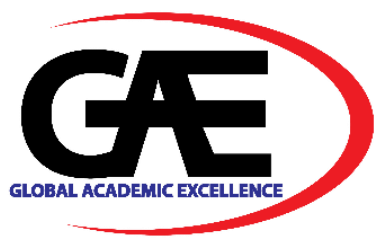

\title{
THE IMPACT OF ONLINE PRODUCT REVIEWS IN VIRTUAL COMMUNITY TOWARDS PURCHASE DECISIONS IN INDONESIAN DENIM INDUSTRY
}

\author{
R. B. M. Cemal Ecmal Rachmat ${ }^{1 *}$ \\ 1 School of Business and Management, Institut Teknologi Bandung, Indonesia \\ Email: raden_bagus@sbm-itb.ac.id \\ Corresponding Author
}

\begin{abstract}
Article Info:
Article history:

Received date: 28.06 .2021

Revised date: 14.07 .2021

Accepted date: 28.07 .2021

Published date: 01.09.2021

To cite this document:

Rachmat, R. B. M. C. E. (2021). The The Impact Of Online Product Reviews In Virtual Community Towards Purchase Decisions In Indonesian Denim Industry. Advanced International Journal of Business, Entrepreneurship and SMEs, 3 (9), 47-66.
\end{abstract}

DOI: $10.35631 /$ AIJBES.39005.

This work is licensed under CC BY 4.0

\begin{abstract}
:
In this study, the researcher uses a combination of the theory of planned behavior and the model of goal-directed behavior to map what effects online product reviews can have on consumer purchase decisions. The researcher hypothesizes that the two adapted theories contain factors that can positively influence consumer purchase decisions. The researcher uses PLS-SEM and open coding to analyze quantitative and qualitative data. The results showed that ten of the eighteen hypotheses tested were proven to be accepted. Consumers in the denim industry tend to perceive online product reviews as a key aspect of their decision-making process. The results of qualitative data analysis also showed similar results, all respondents indicated the importance of the influence of an online product review on their purchasing decisions. The researcher also discusses the implications of these results for both research and practice.
\end{abstract}

Keywords:

Online Product Review, Purchase Decision, Purchase Intention, Virtual Community

\section{Introduction}

Lately, jeans have transformed from being just a compliment in the world of fashion into a trend that seems endless to discuss. According to Maryati (2010), a trend is a movement (tendency) to go up or down in the long term, which is obtained from the average change over time. The rate of change can increase or decrease. According to Andriansyah (2020), the Copyright (C) GLOBAL ACADEMIC EXCELLENCE (M) SDN BHD - All rights reserved 
Volume 3 Issue 9 (September 2021) PP. 47-66 DOI 10.35631/AIJBES.39005

development of the denim trend itself in Indonesia has grown rapidly. In 2012, denim enthusiasts are increasing because it is not only for style, but denim can become an art. Until now, based on the number of brands participating in the biggest annual denim event in Indonesia, the Wall of Fades, as of 2020 there have been more than 20 independent brands operating in the denim industry in Indonesia.

Along with the development of technology and information in Indonesia, social media and virtual communities are examples of several important factors that support the development of denim trends in Indonesia. According to Rheingold (2000), a virtual community is a group of people who exchange thoughts or ideas through digital media, whether or not they have met directly. While the community itself is a group of people who have the same interest in something caused by several factors (communication, a place to gather, certain habits, and the process of creating ideas) which in turn make community members continuously involved (Delobelle, 2008).

Until now, there have been several virtual communities for denim enthusiasts in Indonesia, namely INDIGO (Rizal, 2013). INDIGO is a community for denim enthusiasts to exchange opinions, get information, and virtually explore the history of denim itself. INDIGO initially used the www.kaskus.com platform as a means of communication between its members before finally deciding to make Darahkubiru their independent platform for exchanging ideas and sharing ideas, which was created by INDIGO as an effort to create a special forum for denim fans that previously only could exchange ideas through the forum under the auspices of www.kaskus.com.

According to the official website, Darahkubiru itself is an online magazine that specifically discusses topics around denim-based products which are created as a form of enthusiasm for denim products that a group of people want to exchange ideas. This forum was founded in 2009 by Direz Zender. Furthermore, it is a place where denim enthusiasts can discuss, sell, and develop local brands made by INDIGO members (Rizal, 2013). During its development in Indonesia, Darahkubiru has had a tremendous impact. On the official page of Darahkubiru itself, there is a special segment that discusses education related to denim, product reviews, and forums for online discussions. The event that is scheduled annually by Darahkubiru for denim enthusiasts in Indonesia such as the Wall of Fades is also a clear proof of the impact that this virtual community has given. Based on that situation, one of the important roles of the virtual community is as a forum for education, and one of the information sought as a means of education is an online product review.

According to Khammash (2009), online product reviews in virtual communities is a word of mouth which spreads through electronic media (e-WOM), which explains that online reviews can be implemented as a medium so that consumers can see reviews from other consumers of a product, company service and about how about a company. Without realizing it, the means of providing online reviews has become one of the factors influencing customers shopping decisions. The Consumer Behavior Model suggests that consumer purchasing behavior generally goes through 5 stages, before and after the actual purchase, including recognition of needs, information seeking, evaluation of alternatives, purchasing decisions and post-purchase behavior (Kotler and Keller, 2012). According to Suhari (2012), online product reviews (eWom) is part of external search that comes from outside the consumer's, which will ultimately impact the evaluation of alternatives, since potential consumers can interpret the online product 
reviews to verify a claim to be an acceptable assessment (Salganik, Dodds, and Watts 2006; Salganik and Watts 2008).

Based on this phenomenon, the primary objectives of the study are the following:

1. To explore the behavior of the denim virtual community participants in Indonesian denim industry.

2. To test the effects of online product review on the virtual community towards the customer purchase decision of denim products in Indonesia.

3. To develop marketing recommendations for denim brand marketers that can be implemented as an effort to promote denim products/brands in Indonesia.

\section{Literature Review}

\section{Virtual Community}

Virtual communities are identified as individuals with common interests or objectives for whom electronic communication is a primary mode of communication (Dennis, Pootheri, \& Natarajan, 1998). In order to create relationships, share mutual goals and values, and provide social support, virtual communities bring together people. Based on research an additional role of virtual communities is economic exchange, e.g., Hagel and Armstrong (1997), Pentina et al. (2008), and Zhou et al. (2007). Ridings et al. (2006) describe individuals are motivated to engage in online shopping activities in virtual communities, particularly when individuals have strong social links and trust between members.

\section{Online Product Review}

According to Khammash (2009), online product reviews in virtual communities are a form of electronic word of mouth (e-WOM), which explains that online reviews can be carried out as a medium so that consumers can see reviews from other consumers about the product, the company service and the company. Without realizing it, the means of providing online reviews have become one of the factors that have influenced customer shopping decisions. Increasing numbers of marketing scholars have highlighted the impact of online product reviews, including in the areas of sales and marketing strategies (e.g., Chen, Wang, \& Xie, 2011; Cui, Lui, \& Guo, 2012) and consumer decisions (Sen \& Lerman, 2007; Smith, Menon, \& Sivakumar, 2005). Others looked at the value of online sales forecast reviews (Dellarocas, Zhang, \& Awad, 2007) and consumer motivations for posting reviews (Chen et al., 2011).

\section{Information Content}

According to uncertainty reduction theory and similar hypotheses, further verbal contact between communication partners alleviates uncertainty during initial interactions. Racherla et al. (2012) define informational content as verbal contact that occurs over a virtual medium, additionally, the duration and scope of the initial stages of communication help to alleviate uncertainty and build trust between the communicating parties the research also identified informational content as a critical predictor of confidence. Because online product reviews themselves come in the form of messages that do not have a definite structure, the volume of information presented is a crucial aspect in determining the accuracy of the review in question.

\section{Perceived Similarity}

The uncertainty-reduction theory suggests communication partners to carry out several strategies such as exchanging sociodemographic data which will give them an idea of each other's attitudes, especially at the beginning of the interaction. Contact between individuals 
Volume 3 Issue 9 (September 2021) PP. 47-66 DOI 10.35631/AIJBES.39005

who have the same interests and backgrounds is verbally proven to be much more effective than verbal contact between individuals who do not (Gilly et al., 1998). Knowing the source of information is an advantage for consumers because it can help them find common information they can trust. One of the primary distinctions between conventional and electronic word-ofmouth is the depth of consumer ties.

\section{Trust in the Review}

According to Mayer and Davis (1999), trust is the willingness of a person or a party to allow the actions of another party assuming that the trusted party can take actions that produce the output desired by the creditor, regardless of external or internal factors that can provide uncertainty about the results obtained. Uncertainty itself is a condition that is in the opposite position of trust, where if the uncertainty is at a high level, then how much confidence will it be at a low level, and vice versa. Therefore, it can be concluded that efforts to minimize uncertainty are a strategy to increase trust. While the term willingness itself is interpreted as the viewpoint of the giver of trust who considers that the person given the trust is an expert, competent, and can be responsible for the trust given. According to Grewal et al. (1994), the level of trust is directly influenced by the way each individual interprets information.

\section{Perceived Helpfulness}

A helpful online review is defined as an online review's perceived capacity to assist consumers in evaluating the quality of products sold online and help consumers' decision making process (Li et al., 2013). Online merchants also use the 'helpfulness' review as the key metric for gauging how customers perceive the review. Cheung et al., (2008) described the review's perceived helpfulness as a major indicator of the consumer's decision to obey the reviewers' perspective. In other studies, Ghose and Ipeirotis (2011) claimed that the review helpfulness is positively influencing the overall sale, with the influence being stronger for uncommon products (Zhu et al., 2010). A possible reason is that it is more difficult to locate additional sources of knowledge for less common products, and customers rely heavily on helpful reviews.

\section{Attitude towards the Review}

Mitchell \& Olson (1981) described attitude as an overall consumer assessment regarding the quality of a product that is good or not. In another study, Keller et al. (2011) defined attitude as a response from consumers to a phenomenon, be it positive or negative, which has a significant influence on customer's desire to obtain more and more information about the brand and the product. In a similar theory regarding attitude, Eagly \& Chaiken (1993) states that the object of behavior is determined by both personal and normative factors. According to the Theory of Planned Behavior (TPB), an individual's personal purpose to behave is a feature of his or her attitude toward behavior. Because of TPB's parsimony, it has been widely used for over 20 years (Ajzen, 1991). Adapting from this theory, the researcher builds a hypothesis that attitude towards reviews affects the willingness of virtual community members to participate.

\section{Anticipated Emotions}

Ortony et al. (1988) claimed that anticipated emotions are identical with outlook based emotions. Weiner (1992) concluded that the situation in which an individual has hope of success and has a fear of rejection are factors that influence behavior in the settlement process. In another study, Zeelenberg (1999) also proved that anticipated emotions are an important aspect that affects the decision-making process. As evidence of their contribution to the decision-making process, Ordonez et al. (1999) have proven the effect of negative anticipated 
emotions on the process of selecting options in the series of decision-making processes, Simonson (1992) conducted research on the effect of regret in consumer's decision, finally, March and Shapira (1987) observe that managers' ability to take risks is influenced by both their positive and negative anticipated emotions.

\section{Subjective Norm}

Autio et al. (1997) symbolizes subjective norms as a level of tolerance related to the practice of certain customs or behaviors that come from the surrounding environment such as family, relatives, to friends. Taylor \& Todd (1995) concluded that a person's views, behavior, and attitudes can have a major influence on a person's decision-making process. In another study, Byabashaija \& Katono (2011) proved the assumption in this study, the presumption is that the more desirable the social standard, the more likely it is that the behavior will occur.

\section{Group Norm}

According to Postmes et al, (2001), group norm is a law or situational standard upheld by group members that can be applied to themselves and other group members in the same group who are very likely to have significant differences with social norms. According to Levine \& Moreland, (1991); Hofstede, (1980), each group has its own norm which is a form of the values of its members, which at the group level can have a significant effect on members' compliance with a particular idea or solution. In some case studies, logical thinking can be viewed as positive, but in the majority of cases, groups do sometimes regulate the freedom of thought of each member.

\section{Past Behavior}

By integrating behavioral output frequency, the MGB considers the role of automatic and habitual decision-making processes. Generally, the frequency of past behavior is regarded as factors affecting people behavior and can have an influence on the decision-making process of an individual. Perugini and Bagozzi, (2001), claimed that when a person consistently and habitually engages in a particular behavior, it strengthens an individual's future desire and intention.

Numerous attitudes and behavioral studies have established a strong relationship between future and past behavior (Leone et al., 2004; Oullett \& Wood, 1998), and the role of past behavior frequency as a factor affecting behavior intensity (Perugini \& Bagozzi, 2001; Leone et al. al., 2004). Marks and Olson, (1981), explained that a higher frequency than previous experiences may have a higher effect on similarity than those without or having minimal prior behavior. Numerous studies using MGB have discovered correlations between these three variables (previous behavior, desire, and intent) (Meng and Han, 2016; Kim and Preis, 2016; Meng and Choi, 2016).

\section{Perceived Behavioral Control}

Ajzen (1991) defined perceived behavioral control as an individual's expectations of the ease and complexity of expressing an interesting attitude. According to Kang et al., (2006); Chen, (2007), perceived behavioral control may account for substantial differences in behavioral intentions and behaviors and is closely related to the level of control a person perceives over behavioral conduct. In that case, Ajzen, (1991) added that the participation level in a particular activity is strongly affected by an individual's level of control. Individual's expectations of control improve significantly as they think that they have time, money, and capabilities. As a result, their behavioral intentions increase. Therefore, the intention to purchase the product 
tends to be higher when individuals have more control over the purchase of the goods, including the desire, before they turn into a real intention.

\section{Social Identity}

According to Turner and Tajfel (1979), identity is the process through which individuals identify their own identities in relation to perceived social group membership, as if through work to safeguard or promote self-identity. Gazi, (2014) claimed that the social identity influence depends on an individual's security and self-concept. In other studies, Feather \& Rauter, (2004); Bartels and Onwezen, (2014), showed that social identity is indeed a good predictor of desirable actions in both the marketing and organizational contexts. Social identity is inextricably linked to persistent categorizations such as race, gender, and identity (Stets and Burke, 2003).

\section{Desire}

One of the new theories conveyed through the Model of Goal-Directed Behavior is the role of desire as a mediator between attitude, subjective norms, and anticipated emotions, with intentions. Desire is also often considered a mediator of the effect of perceived behavioral control in several studies using MGB. Bagozzi, (1992) and Fazio, (1995) claimed that attitude theory or TPB is often difficult to map how a decision-making process is stimulated. The critique is while attitudes, anticipated emotions, and subjective norms, and others are generally defined as direct determinants of intent provide justifications for action, they lack the motivating substance necessary to elicit an intention to act. Desires can be an intermediary that serves as a determining variable of intentions, channeling the influence of classical "reasoned" precedents on decisions and intentions (Bagozzi, 1992).

\section{Purchase Intention}

Pavlou \& Fygenson, (2006) stated that studies related to the Technology Acceptance Model (TAM), Theory of Planned Behavior (TPB), and Theory of Reasoned Action (TRA) have proven customers' intention to participate both online and offline as a reliable factor of actual participation of consumers. The relation between actions and intention is premised on the belief that human beings are attempting to create reasonable choices according to available data or information. Thus, Ajzen \& Fishbein (1980) claimed that an individual's behavioral purpose to conduct (refrain from performing) action is a factor that can directly assess its effect on an individual's actual actions.

\section{Purchase Decision}

The purchase decision is a series of options made by a buyer prior to making a purchase, beginning with his or her willingness to meet a need. The customer must choose the location of the purchase, the desired brand and model, the quantity of the purchase, the time of the purchase, the total of resources to allocate or even the payment method. Marketers can affect these decision-making processes by supplying information related to the products or services they offer. Consumers would typically seek knowledge relevant to their own needs before seeking external information (Schiffman and Kanuk, 2007). Schiffman and Kanuk, (2007) also viewed prior purchase history as an internal source of knowledge on which the buyer relies when making a decision. A number of customer decisions tend to be affected by the combination of previous purchase behavior, marketing campaigns, and external user-generated contents as their sources. Chaipradermsak, (2007) claimed that prior research has shown that customers generally seek to reduce risk when making purchase decisions. 


\section{Conceptual Framework}

Based on the Model of Goal-Directed Behavior (Perugini \& Bagozzi, 2001), Theory of Planned Behavior (Ajzen 1985; 1991), and an evaluation of the results of studies related to this research, a conceptual framework and hypotheses are generated. The following is the conceptual framework proposed for this research.

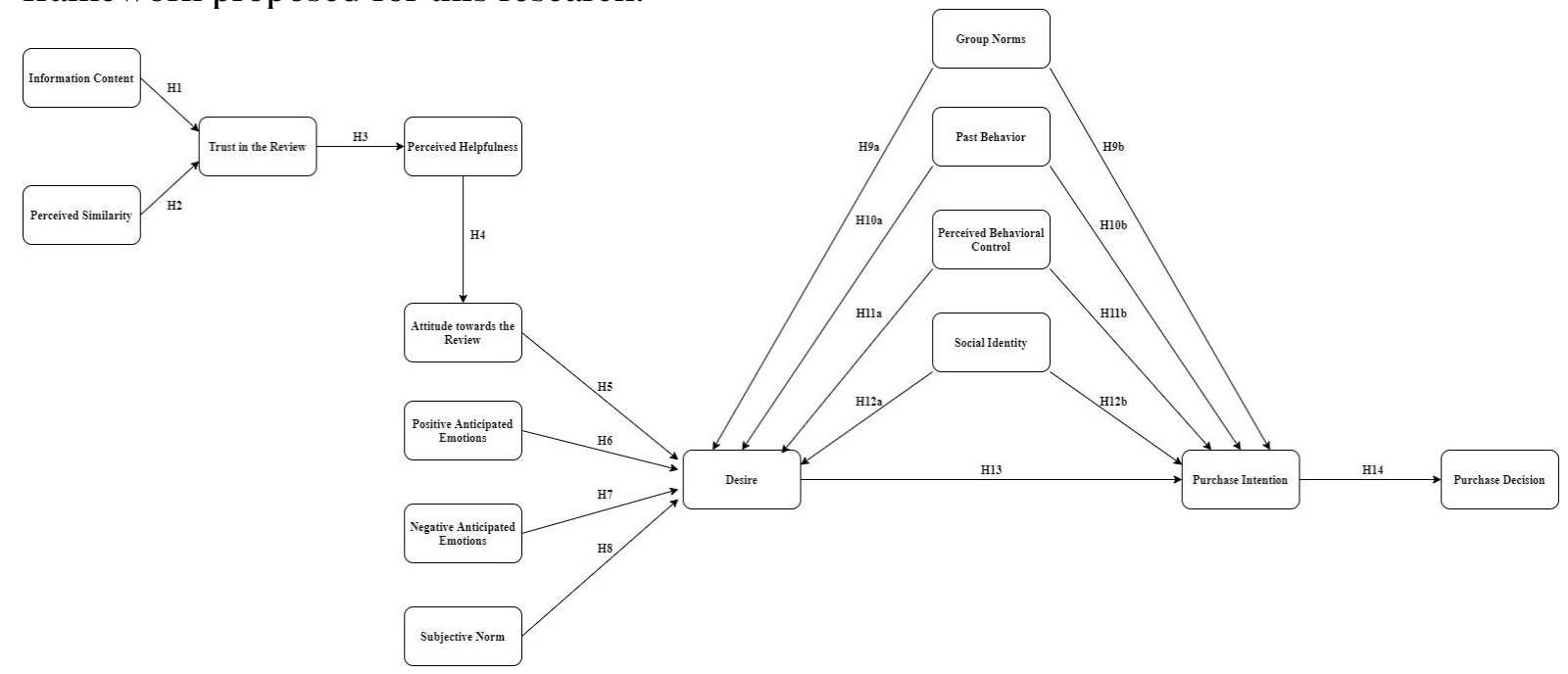

Source: Author's Interpretation

\section{Figure 1: Conceptual Framework}

\section{Hypotheses:}

H1: Information content positively influences consumers' trust in the review.

H2: Perceived similarity positively influences consumers' trust in the review.

H3: Review readers' trust in the reviews positively influences perceived helpfulness.

H4: Perceived helpfulness will have a positive influence on attitude towards the reviews.

H5: Attitude towards the review positively influences customer's desire.

H6: Positive Anticipated Emotions positively influence customer's desire.

H7: Negative Anticipated Emotions positively influence customer's desire.

H8: Subjective norms positively influence customers' desire.

H9a: Group norms positively influence customers' desire.

H9b: Group norms positively influence customers' purchase intention.

H10a: Past behavior positively influences customers' desire.

H10b: Past behavior positively influences customers' purchase intention.

H11a: Perceived behavioral control positively influences customers' desire.

H11b: Perceived behavioral control positively influences customers' purchase intention.

H12a: Social identity positively influences customers' desire.

H12b: Social identity positively influences customers' purchase intention.

H13: Customers' desire positively influences customers' purchase intention.

H14: Customers' purchase intention positively influences consumers' purchase decisions to buy the product.

\section{Research Methodology}

The process involves exploratory research to assess the phenomenon and issues affecting the denim virtual community's purchase decisions. Following that, issues that can be found are identified. The study of the findings and hypotheses of previous studies that may be relevant to the investigation. This study will use both qualitative and quantitative approaches. Thus, 
both interviews and questionnaires are used to obtain data. The results of the interviews and questionnaires will be analyzed so that the researcher can draw conclusions and recommendations.

The interview respondents needed in this study are individuals who are potential customers of denim products and become members of the denim virtual community. Through the experiences of respondents as members of the denim virtual community, respondents have the capacity and knowledge to provide insights for this research. In this research, the researcher uses non-probability sampling since the researcher does not confirm that all of the denim virtual community members have the same probability of being chosen. The researcher will analyze qualitative data obtained by highlighting and labeling significant pieces the interview results. The data that has been labeled will be further classified. The aim of this assignment is to create a descriptive, multi-dimensional preliminary framework for subsequent study. Since it is constructed directly from raw data, the method itself guarantees the work's validity.

The population of this research questionnaire consists of men and women domiciled in Indonesia, who have bought denim products (shoes, bags, clothes, and any fashion attribute) after/while their participation in the denim virtual community. In this study, all quantitative indicators will be measured on a 5-point Likert-type scale ranging from "strongly disagree" (1) to "strongly agree" (5), and the results will be distributed to the general public via an online survey. The researcher analyzed a total of 207 respondents for this research. The sampling technique used is survey technique, the researcher uses judgment sampling because the researcher chooses what kind of respondent criteria are appropriate in this study and each individual who meets the criteria as a respondent does not have the same possibility of becoming a respondent. The researcher will analyze quantitative data obtained using SmartPLS. The process includes reliability test, validity test, collinearity test, structural path significance test, $\mathrm{R}^{2}$ and $\mathrm{Q}^{2}$ test, F Square effect size, total indirect, total effect, and mediation result, before moving on to the hypothesis testing.

\section{Discussions and Analysis}

Table 1: PLS-SEM Hypothesis Testing Result

\begin{tabular}{|c|c|c|c|c|}
\hline Hypothesis & Structural Path & T Values & P Values & Result \\
\hline H1 & $\begin{array}{l}\text { Information Content }->\text { trust in the } \\
\text { Review }\end{array}$ & 2.769 & 0.006 & Accepted \\
\hline $\mathrm{H} 2$ & $\begin{array}{l}\text { Perceived Similarity } \rightarrow \text { trust in the } \\
\text { Review }\end{array}$ & 9.231 & 0.000 & Accepted \\
\hline H3 & $\begin{array}{l}\text { trust in the Review } \rightarrow \text { Perceived } \\
\text { Helpfulness }\end{array}$ & 9.197 & 0.000 & Accepted \\
\hline $\mathrm{H} 4$ & $\begin{array}{l}\text { Perceived Helpfulness } \rightarrow \text { Attitude } \\
\text { towards the Review }\end{array}$ & 12.485 & 0.000 & Accepted \\
\hline H5 & $\begin{array}{l}\text { Attitude towards the Review } \rightarrow> \\
\text { Desire }\end{array}$ & 0.871 & 0.384 & Rejected \\
\hline H6 & $\begin{array}{l}\text { Positive Anticipated Emotions } \quad-> \\
\text { Desire }\end{array}$ & 1.414 & 0.158 & Rejected \\
\hline
\end{tabular}


Volume 3 Issue 9 (September 2021) PP. 47-66 DOI 10.35631/AIJBES.39005

\begin{tabular}{|l|l|l|l|l|}
\hline $\mathrm{H} 7$ & $\begin{array}{l}\text { Negative Anticipated Emotions -> } \\
\text { Desire }\end{array}$ & 0.841 & 0.401 & Rejected \\
\hline $\mathrm{H} 8$ & Subjective Norm -> Desire & 1.284 & 0.200 & Rejected \\
\hline $\mathrm{H} 9 \mathrm{a}$ & Group Norm -> Desire & 0.969 & 0.333 & Rejected \\
\hline $\mathrm{H} 9 \mathrm{~b}$ & Group Norm -> Purchase Intention & 2.410 & 0.016 & Accepted \\
\hline $\mathrm{H} 10 \mathrm{a}$ & Past Behavior -> Desire & 3.383 & 0.001 & Accepted \\
\hline $\mathrm{H} 10 \mathrm{~b}$ & Past Behavior -> Purchase Intention & 1.115 & 0.265 & Rejected \\
\hline $\mathrm{H} 11 \mathrm{a}$ & $\begin{array}{l}\text { Perceived Behavioral Control -> } \\
\text { Desire }\end{array}$ & 0.999 & 0.318 & Rejected \\
\hline $\mathrm{H} 11 \mathrm{~b}$ & $\begin{array}{l}\text { Perceived Behavioral Control -> } \\
\text { Purchase Intention }\end{array}$ & 1.975 & 0.049 & Accepted \\
\hline $\mathrm{H} 12 \mathrm{a}$ & Social Identity -> Desire & 4.403 & 0.000 & Accepted \\
\hline $\mathrm{H} 12 \mathrm{~b}$ & Social Identity -> Purchase Intention & 1.725 & 0.085 & Rejected \\
\hline $\mathrm{H} 13$ & Desire -> Purchase Intention & 4.748 & 0.000 & Accepted \\
\hline $\mathrm{H} 14$ & $\begin{array}{l}\text { Purchase Intention -> Purchase } \\
\text { Decision }\end{array}$ & 6.682 & 0.000 & Accepted \\
\hline
\end{tabular}

\section{Information Content Has Positive Influence On Consumers' Trust In The Review}

Based on the results obtained, it can be concluded that there is a positive influence given by information content on consumers' trust in the review. All data obtained through questionnaires and interviews indicate that trust is strongly influenced by the content provided in the review. Aspects of detailed information, comprehensive, also provides a product shortage is very influential on the trust of respondents. This result is also in line with the results of previous research conducted by Furner et al. (2012) which concluded that the information content positively influenced trust in the reviews.

\section{Perceived Similarity Has Positive Influence On Consumers' Trust In The Review}

Based on the results obtained, it can be concluded that there is a positive influence given by perceived similarity to consumers' trust in the review. All data obtained through questionnaires and interviews indicate that trust is strongly influenced by the similarity between reviewers and readers. Aspects such as the similarity of tastes, the similarity of views, to the similarity of how to wear denim between reviewers and readers greatly affect the respondents' beliefs. This result is also in line with the results of previous research conducted by Racherla et al. (2012) who found that perceived similarity positively influenced trust in a review and played a significant role in it.

\section{Review Readers' Trust In The Review Has Positive Influence On Perceived Helpfulness}

Based on the data obtained, it can be concluded that the reader's trust in the review read has a positive influence on perceived helpfulness. Both the results obtained through questionnaires and interviews, showed a similar trend. These results were obtained for various reasons, the first is because trust itself is one of the components that make up perceived helpfulness, the second is the reviewers in the virtual denim community who are mostly experts in the denim field, the last is the image that has been built since its inception by Denim virtual community that has always been well maintained until now. This result is also in line with previous research Copyright (C) GLOBAL ACADEMIC EXCELLENCE (M) SDN BHD - All rights reserved 
by Malik et al. (2017) which shows the significant influence given by the factors of trust, joy, anger, and sadness on review helpfulness.

\section{Perceived Helpfulness Has Positive Influence On Attitude Towards The Review}

As we can see from the data that has been obtained, perceived helpfulness is proven to have a positive influence on customers' attitudes towards the review. These results further indicate that perceived helpfulness is one of the most important indicators that can trigger a positive attitude from customers towards a review as has been proven by previous research by Walther et al. (2012) who shown that perceived helpfulness is critical, and also proven to have a role in improving perceived helpfulness results in more favorable attitudes toward online reviews. Both quantitative and qualitative methods used also support these results in harmony.

\section{Attitude Towards The Review Does Not Have Positive Influence On Customers' Desire}

As can be seen in the results of the previous hypothesis testing, the effect of attitude towards the review on customers' desire is rejected. This result is also supported by the statements given by the respondents in the interviews that have been held. This result is certainly not in line with research conducted by Ko (2018) which states that the level of attitude toward reviews positively influences consumers' desire in buying and selling activities. This result is very likely due to the role of denim products which are still classified as tertiary needs which cause consumers to have a tendency to resist the urge from reviews for them to want a denim product, the condition is different if they have the intention to buy denim products before reading a review.

\section{Positive And Negative Anticipated Emotions Do Not Have Positive Influence On Customers' Desire}

Both positive and negative anticipated emotions proved not to have a positive effect on customers' desire, this result is very visible from the results of the questionnaire which showed the rejection of the majority of respondents. Of course, these results are not in line with previous studies conducted by Bagozzi et al. (2016) which states that the two kinds of anticipated emotions (AEs) have a high level of influence towards consumers' desire. The most possible explanation regarding this result is that the majority of respondents have reached the age classified as adults so that they have higher mental stability than the age group of children or adolescents. This is most likely to cause respondents to reject the majority of statements that say that positive and negative emotions played a huge role in their desire to buy something.

\section{Subjective Norms Do Not Have Positive Influence On Customers' Desire}

As can be seen from the results obtained, the relationship between subjective norms and customers' desire is rejected. Of course, these results are not in line with the results obtained by previous studies conducted by Tajeddini et al. (2014) who found that subjective norms positively influence an individual's early stage of decision making process (desire) towards intention to purchase in the cosmetic industry. The most plausible reason for this result is that different industries have different consumer components as well. In previous studies, the majority of respondents were women while in this study, the majority of respondents were men, although both studies have a similar age range of respondents, this argument is also strengthened by the results of a similar study conducted by Haro (2018) which states that customers' desire to buy halal cosmetics is positively affected by subjective norms which also discuss the same industry as research conducted by Tajeddini et al. (2014). There is also the possibility that men have a tendency to not follow the subjective norms around them, especially if these norms are not in line with their personality. 


\section{Group Norms Do Not Have Positive Influence On Customers' Desire}

As can be seen from the results obtained, the relationship between group norms and customers' desire is rejected. Of course, these results are not in line with the results obtained by previous studies conducted by Postmes et al. (2001) which states that group norms have a positive influence towards desire as part of the decision-making process. This result can be caused by the condition of the scope of the respondent's friendship who does not have the same perception regarding denim products as the respondent feels. Therefore, when respondents are faced with statements stating that they have a circle of friends who also like denim products and can be imitated/followed, they tend to reject these statements. Another reason is because an individual who has no interest at all in a product (in this case denim products) has a tendency to resist stimulants from group norms to trigger their desire for the product.

\section{Group Norms Have Positive Influence On Customers' Purchase Intention}

As can be seen from the results obtained, the relationship between group norms and customers' desire is accepted. Group norms are proven to have a positive influence on customers' desire. These results are in line with the results obtained in previous studies conducted by Al Nahdi et al. (2015) which states that the higher the group norm value, the higher the purchase intention value of consumers towards purchasing properties in UAE. Getting this result is thought to occur because customers already have the desire to buy a product so that group norms have a higher influence on being able to influence purchase intention.

\section{Past Behavior Has Positive Influence On Customers' Desire}

Based on the results obtained, past behavior is proven to have a positive influence on customers' desire. Based on the results of data processing, the hypothesis was accepted. This result is in line with previous research which states that the frequency of past behavior is an important factor in determining customers' desire before it evolves to consumers' purchase intentions (Meng and Choi, 2016).

\section{Past Behavior Does Not Have Positive Influence On Customers' Purchase Intention}

Based on the results obtained from the data processing, the relationship between past behavior and customers' purchase intention is rejected. This result is not aligned with the previous research which stated that past purchasing behavior has a positive but insignificant influence towards purchase intention (Zheng \& Chi, 2014). The most possible explanation about this result is the availability of many other features that play a larger role in the denim virtual community that can influence consumer purchase intentions such as information from product reviews, opinions of other members, as well as the availability of many other product options to choose from, thus reducing the impact of past behavior on the customers current behavior.

\section{Perceived Behavioral Control Does Not Have Positive Influence On Customers' Desire}

Based on the results of data processing that has been done previously, perceived behavioral control has no positive effect on customers' desire. This result is not in line with the statement of Suha \& Sharif (2018) which states that perceived behavioral control has a significant effect on the purchasing decision process, one of which is customers' desire. The possible reason for this result to occur is that the control a potential buyer has does not affect his or her interest in a product. Perceived behavioral control will only increase the purchase intention that was previously intended by the individual concerned. 
Volume 3 Issue 9 (September 2021) PP. 47-66 DOI 10.35631/AIJBES.39005

Perceived Behavioral Control Has Positive Influence On Customers' Purchase Intention Based on the results obtained, perceived behavioral control is proven to have a positive influence on customers' purchase intention. With these results, aspects of control over purchases, control over ownership of goods, as well as resources to obtain the desired goods have proven to have a positive effect on purchase intention. This result is also in accordance with the results of previous research which states that there are positive significant influences in the relationships between purchase intention and actual purchase (Suha \& Sharif, 2018).

\section{Social Identity Has Positive Influence On Customers' Desire}

As we can see based on the results obtained, social identity has a positive influence on customers' desire. These results prove that the effect of denim products as self-identity, the use of denim products, and a sense of pleasure or pride when wearing denim products are indicators that can influence customers' desire to return to increase ownership of denim products in the future. This result is also in line with previous research by Bagozzi \& Dholakia (2002) which states that social identity has a high level of effect towards desires.

\section{Social Identity Does Not Have Positive Influence On Customers' Purchase Intention}

As we can see based on the results that have been obtained, social identity is proven to have no positive influence on customers' purchase intention. These results break the opinion which states that the effects of denim products as self-identity, the use of denim products, and feelings of pleasure or pride when wearing denim products are indicators that can influence customers' purchase intention. The results obtained are not in line with previous research by McGowan et al. (2016) which states that social identity positively influences the purchase intention of identity-linked products although it is insignificant. The weak relationship between the two variables can be caused by the tendency of denim owners to keep using a denim product for a long time, which ranges from 1 or 2 years, or even more. This condition reduces the influence of social identity on consumers' purchase intentions because they tend to still use the denim products they have purchased before.

\section{Customers' Desire Has Positive Influence On Customers' Purchase Intention}

Based on the results obtained through quantitative methods and qualitative methods that have been carried out, it can be concluded that customers' desire has a positive influence on customers' purchase intention. In interviews that have been conducted, respondents also stated the importance of the role of online product reviews in the denim virtual community in the process, this result is also in line with previous research which found that desires have provided critical effects towards purchase intention (Perugini \& Bagozzi, 2001); desire serves to generate customers' buying intentions, which serves to continue the process of changing customers' behavior (Perugini \& Bagozzi, 2004).

\section{Customers' Purchase Intention Has Positive Influence On Customers' Purchase Decision}

Based on the results obtained through both quantitative methods and qualitative methods that have been carried out, it can be concluded that customers' purchase intention has a positive influence on customers' purchase decision. In interviews that have been conducted, respondents explicitly stated the importance of online product reviews in the denim virtual community on their final decision regarding whether to make a purchase or not, this result is also in line with previous research which found that a higher level of purchasing intention has a bigger probability to become an actual purchase (Kim et al., 2008); purchase intention is positively associated with purchase behavior for environmentally friendly goods (Kumar et al., 2004); there are positive significant influences in the relationships between purchase intention and 
actual purchase (purchase decisions process) (Suha \& Sharif, 2018). Through online product reviews given in the denim virtual community, customers will certainly have more information regarding the products they previously planned to buy which in the end is also related to their final decision regarding making an actual purchase or not.

\section{Conclusions}

As stated in the first chapter, the objectives of this research are to explore the behavior of the denim virtual community participants in the Indonesian denim industry, test the effects of online product review on the virtual community towards the customer purchase decision of denim products, and to develop marketing recommendations for denim products/brand marketers that can be implemented as an effort to promote denim products/brands in Indonesia. The researcher has thoroughly analyzed all the data obtained through a quantitative approach (questionnaire) with analysis using SmartPLS and a qualitative approach (interview) with an open coding analysis of members and participants from the denim virtual community. In addition to explaining the influence of online product reviews in the denim virtual community on purchase decisions, the researcher will also provide recommendations for denim brand marketers that can be implemented so that the denim industry in Indonesia can grow rapidly.

\section{Research Objective 1: How Is The Behavior Of The Denim Enthusiast Virtual Community Participants In Indonesia}

The results of the research show that the behavior of consumers in the denim industry in Indonesia is to look for online product reviews as a source of information, consideration, and one of the key factors that influence their purchasing decisions. Due to the image of the denim virtual community that has been well developed over a long period of time, as well as the limited space for providing reviews of denim products, the denim virtual community has become a key channel for denim enthusiasts to obtain information.

In addition, respondents also showed a tendency to actively participate and contribute to the denim virtual community, both online and in person through its annual event, Wall of Fades. If viewed from the perspective of the Model of Goal-directed Behavior used in this research, it can be concluded that the attitude factor, anticipated emotions, and subjective norms are proven not to represent the behavior of denim product consumers based on the results of data processing. On the other hand, the factors of group norms, past behavior, perceived behavioral control, and social identity are proven to represent consumers of denim products, although not as a whole.

\section{Research Objective 2: What Are The Effects Of Online Product Review On The Virtual Community Towards The Purchase Decision Of Denim Products In Indonesia}

Through data calculations using SmartPLS, online product reviews on denim virtual communities are proven to have a significant influence on denim products customers' purchase decisions. This result is also supported by the analysis of mediating results which shows the results as partial mediation of the five mediating variables tested, these results indicate that online product reviews have a direct relationship to customer purchase decisions.

In the analysis of quantitative data obtained, from 187 respondents who stated that they had read online product reviews in the denim virtual community, $85 \%$ of them gave answers stating that online product reviews in the denim virtual community were a factor that influenced them to buy denim products. The results of the analysis of the qualitative data collected also indicate results that are similar to the results of the analysis of quantitative data. All respondents 
Volume 3 Issue 9 (September 2021) PP. 47-66 DOI 10.35631/AIJBES.39005

explicitly stated that online product reviews greatly influence their purchasing decisions, starting with information seeking, product evaluation, to the final purchase decision.

\section{Research Objective 3: What Marketing Recommendations Can Denim Brand Marketers Implement As An Effort To Promote Their Products}

Overall, this research suggests optimizing several aspects of the marketing strategy for denim brand marketers. The first is optimizing content that is distributed through Instagram, according to research results, as many as $45.3 \%$ of participants in the denim virtual community use the Instagram platform as a medium for their participation, with the main focus on finding educational content and tutorials. Next is optimizing the target market opportunities from women. Based on the research results, only $3.9 \%$ of the total number of respondents to the questionnaire were women, this indicates that the opportunity to explore the denim market for women is still very wide with a very large target market.

On the other hand, this result suggests that denim brand marketers should always innovate to be able to show their brand identity to their main market which comes from men so that they can maintain their existence, because if viewed from the size of the market which is so large, it can be ascertained that the preferences of every consumer will be different from each other. The last recommendation is optimizing the use of denim virtual community channels in order to increase sales. As previously stated, online product reviews in the denim virtual community play an important role in consumer purchasing decisions, therefore, denim brand marketers must be able to stimulate consumers to be able to share opinions, ideas, and reviews related to their products through the denim virtual community. In addition, the active role of each denim brand in events held by virtual denim communities such as Wall of Fades can also be carried out in order to increase sales and profits.

\section{References}

Ajzen, I. (1991). Theory of planned behavior. Organizational behavior and human decision processes. 50, 179-211.

AL-Nahdi, T. S., Habib, S. A., Abu Bakar, A. H., Bahklah, M. S., Ghazzawi, O. H., \& AlAttas, H. A. (2015). The Effect of Attitude, Dimensions of Subjective Norm, and Perceived Behavior Control, on the Intention to Purchase Real Estate in Saudi Arabia. International Journal of Marketing Studies, 7(5).

Andriansyah, R., 2020. Sejarah Denim Di Indonesia. [online] Communication. Available at: <https://communication.binus.ac.id/2020/01/29/sejarah-denim-di-indonesia/> [Accessed 9 October 2020].

Autio, E., Keeley, R. H., Klofsten, M., \& Ulfstedt, T. (1997). Entrepreneurial Intent Among Students: Testing an Intent Model in Asia, Scandinavia, and USA. Babson College Frontiers of Entrepreneur Research.

Bagozzi, R.P. (1992). The self-regulation of attitudes, intentions and behavior. Social Psychology Quarterly, 55, 178-204.

Bagozzi, R. P., Belanche, D., Casaló, L. V., \& Flavián, C. (2016). The Role of Anticipated Emotions in Purchase Intentions. Psychology \& Marketing, 33(8), 629-645.

Bagozzi, R. P., \& Dholakia, U. M. (2002). Intentional social action in virtual communities. Journal of Interactive Marketing, 16(2), 2-21.

Bagozzi, R. P., Dholakia, U. M., \& Basuroy, S. (2003). How effortful decisions get enacted: the motivating role of decision processes, desires, and anticipated emotions. Journal of Behavioral Decision Making, 16(4), 273-295. 
Volume 3 Issue 9 (September 2021) PP. 47-66 DOI 10.35631/AIJBES.39005

Balakrishnan, B. K. P. D., Dahnil, M. I., \& Yi, W. J. (2014). The Impact of Social Media Marketing Medium toward Purchase Intention and Brand Loyalty among Generation Y. Procedia - Social and Behavioral Sciences, 148, 177-185.

Baron, R. M., \& Kenny, D. A. (1986). The moderator-mediator variable distinction in social psychological research: Conceptual, strategic, and statistical considerations. Journal of Personality and Social Psychology, 51, 1173-1182.

Baron, R. S., Kerr, N. L., \& Miller, N. (1992). Group process, group decision, group action. Pacific Grove, CA: Brooks/Cole.

Bartels, J., \& Onwezen, M. C. (2013). Consumers' willingness to buy products with environmental and ethical claims: the roles of social representations and social identity. International Journal of Consumer Studies, 38(1), 82-89.

Bhat, A. (2017). Quantitative Research: Definition, Methods, Types and Examples | QuestionPro. Questionpro.

Blackwell, R.D., Miniard, P.W. and Engel, J.F. (2001), Consumer Behavior, 9th ed., SouthWestern Thomas Learning, Mason, $\mathrm{OH}$.

Buda, R. (2003) 'The interactive effect of message framing, presentation order and source credibility on recruitment practices', International Journal of Management, Vol. 20, No. 2, pp.156-163.

Byabashaija, W., \& Katono, I. (2011). he Impact of College Entrepreneurial Education on Entrepreneurial Attitudes and Intentions to Start a Business in Uganda. Journal of Developmental Entrepreneurship, 127-144.

Chaipradermsak, T. (2007), "The influential factors on consumers' purchasing decision in Bangkok pet retailing business", MBA Thesis, Shinawatra University.

Chen, M.-F. (2007). Consumer attitudes and purchase intentions in relation to organic foods in Taiwan: Moderating effects of food-related personality traits. Food Quality and Preference, 18(7), 1008-1021.

Chen, Y., Wang, Q., \& Xie, J. (2011). Online social interactions: A natural experiment on word of mouth versus observational learning. Journal of Marketing Research, 48(2), 238254.

Cheung, C.M.K., Lee, M.K.O. and Rabjohn, N. (2008), "The impact of electronic word-ofmouth: the adoption of online opinions in online customer communities", Internet Research, Vol. 18 No. 3, pp. 229-247.

Coyle JR, Smith T, Platt G. "I'm here to help": how companies' microblog responses to consumer problems influence brand perceptions. Journal of Research in Interactive Marketing 2012; 6:27-41.

Cui, G., Lui, H. K., \& Guo, X. (2012). The effect of online consumer reviews on new product sales. International Journal of Electronic Commerce, 17(1), 39-57.

Davis, W.A. (1984). A causal theory of intending. American Philosophical Quarterly, 21, 4354.

Dellarocas, C., Zhang, M. X., \& Awad, N. F. (2007). Exploring the value of online product reviews in forecasting sales: The case of motion pictures. Journal of Interactive Marketing, 21(4), 23-45.

Delobelle, V., 2008. Corporate Community Management By Vanina Delobelle,Phd. [online] Available at: <http://www.vaninadelobelle.com/> [Accessed 1 October 2020].

Dennis, A. R., Pootheri, S. K., \& Natarajan, V. L. (1998). Lessons from the early adopters of web groupware. Journal of Management Information Systems, 14(4), 65-86.

Dillard JP, Shen L. 2005. On the Nature of Reactance and its Role in Persuasive Health Communication. Communication Monographs 72(2): 144-168. 
Volume 3 Issue 9 (September 2021) PP. 47-66 DOI 10.35631/AIJBES.39005

Eagly, A.H., \& Chaiken, S. (1993). The psychology of attitudes. Fort Worth, TX: Harcourt Brace Jovanovich.

Fazio, R.H. (1995). Attitudes as object-evaluation associations: Determinants, consequences, and correlates of attitude accessibility. In R.E. Petty \& J.A. Krosnik (Eds.), Attitude strength: Antecedents and consequences (pp. 247-282). Mahwah, NJ: Erlbaum.

F.D. Davis, Perceived usefulness, perceived ease of use, and user acceptance of information technology, MIS Quarterly 13 (3) (1989) 319-340.

Feather, N. T., \& Rauter, K. A. (2004). Organizational citizenship behaviours in relation to job status, job insecurity, organizational commitment and identification, job satisfaction and work values. Journal of Occupational and Organizational Psychology, 77(1), 8194.

F. Hair Jr, J., Sarstedt, M., Hopkins, L., \& G. Kuppelwieser, V. (2014). Partial least squares structural equation modeling (PLS-SEM). European Business Review, 26(2), 106-121.

Forman C, Ghose A, Wiesenfeld B. 2008. Examining the Relationship Between Reviews and Sales: The Role of Reviewer Identity Disclosure in Electronic Markets. Information Systems Research 19(3): 291-313.

Frankfurt, H. (1988). The importance of what we care about. Cambridge, UK: Cambridge University Press.

Furner, C. P., Racherla, P., \& Zhu, Z. (2012). Uncertainty, trust and purchase intention based on online product reviews: an introduction to a multinational study. International Journal of Networking and Virtual Organisations, 11(3/4), 260.

Gabbiadini, A., Cristini, F., Scacchi, L., \& Monaci, M. G. (2016). Testing the Model of GoalDirected Behavior for Predicting Binge Drinking Among Young People. Substance Use \& Misuse, 52(4), 493-506.

Ghose, A. and Ipeirotis, P.G. (2011), "Estimating the helpfulness and economic impact of product reviews: mining text and reviewer characteristics", IEE Transactions on Knowledge and Data Engineering, Vol. 23 No. 10, pp. 1498-1512.

Ghosh, T. (2017). Predicting hotel book intention: The influential role of helpfulness and advocacy of online reviews. Journal of Hospitality Marketing \& Management, 27(3), 299-322.

Given, L. (2012). Open Coding. The SAGE Encyclopedia of Qualitative Research Methods. https://doi.org/10.4135/9781412963909.n299

Hagel, J. and Armstrong, A., 1997. Net gain. Boston: Harvard Business School.

Hanaysha, J. R. (2018). An examination of the factors affecting consumer's purchase decision in the Malaysian retail market. PSU Research Review, 2(1), 7-23.

Haro, A. (2018). Determinants of Halal Cosmetics Purchase Intention on Indonesian Female Muslim Customers. Journal of Entrepreneurship, Business and Economics, [S.1.], v. 6, n. $1,78-91$

Hayes, A. F. (2009). Beyond Baron and Kenny: Statistical mediation analysis in the new millennium. Communication Monographs, 76(4), 408-420. https://doi.org/10.1080/03637750903310360

Hofstede, G. (1980). Culture's consequences. Beverly Hills, CA: Sage

Huang, L. T., \& Farn, C. K. (2009). Effects of virtual communities on purchasing decisionmaking: The moderating role of information activities. PACIS 2009 - 13th Pacific Asia Conference on Information Systems: IT Services in a Global Environment.

Hutchinson, J.W. (1983), "Expertise and the structure of free recall", in Bagozzi, R.P. and Tybout, A.M. (Eds), Advances in Consumer Research, Association for Consumer Research, Ann Arbor, MI, pp. 434-447. 
Volume 3 Issue 9 (September 2021) PP. 47-66 DOI 10.35631/AIJBES.39005

I. Ajzen, M. Fishbein, Understanding Attitude and Predicting Social Behavior, Prentice-Hall, Inc., Englewood Cliffs, NJ, 1980.

I. Ajzen, The theory of planned behavior, Organizational Behavior and Human Decision Processes 50 (1991) 179-211.

Islam, G. (2014). Social Identity Theory. Encyclopedia of Critical Psychology, 1781-1783.

Kang, H., Hahn, M., Fortin, D. R., Hyun, Y. J., \& Eom, Y. (2006). Effects of perceived behavioral control on the consumer usage intention of e-coupons. Psychology and Marketing, 23(10), 841-864.

Kempf DAS, Palan KM. 2005. The effects of gender and argument strength on the processing of word-of-mouth communication. Academy of Marketing Studies Journal 10(1): 118.

Khammash, M., 2008. ELECTRONIC WORD-OF-MOUTH: ANTECEDENTS OF READING CUSTOMER REVIEWS IN ON-LINE OPINION PLATFORMS: A QUANTITATIVE STUDY FROM THE UK MARKET, .

Kim, H. Y., \& Chung, J.-E. (2011). Consumer Purchase Intention for Organic Personal Care Product. Journal of Consumer Marketing, Vol. 28 Issue: 1, 40-47.

Kim, D. J., Ferrin, D. L., \& Rao, H. R. (2008). A trust-based consumer decision-making model in electronic commerce: The role of trust, perceived risk, and their antecedents. Decision Support Systems, 44(2), 544-564.

Kim, M.J. and Preis, M.W. (2016), "Why seniors use mobile devices: applying an extended model of goal-directed behavior", Journal of Travel \& Tourism Marketing, Vol. 33 No. 3 , pp. 404-423.

Ko, H.-C. (2018). Social desire or commercial desire? The factors driving social sharing and shopping intentions on social commerce platforms. Electronic Commerce Research and Applications, 28, 1-15.

Kotler, P., Keller, K., Ang, S., Tan, C. and Leong, S., 2012. Marketing Management. 14th ed. New Jersey: Prentice Hall, p.166.

Kulviwat S, Bruner II GC, Kumar A, et al. Toward a unified theory of consumer acceptance technology. Psychology and Marketing 2007; 24:1059-1084.

Kumar, B., Manrai, A. K., \& Manrai, L. A. (2017). Purchasing behaviour for environmentally sustainable products: A conceptual framework and empirical study. Journal of Retailing and Consumer Services, 34, 1-9.

Leone, L., Perugini, M. and Ercolani, A.P. (2004), "Studying, practicing, and mastering: a test of the model of goal-directed behavior (MGB) in the software learning domain", Journal of Applied Social Psychology, Vol. 34 No. 9, pp. 1945-1973.

Levine, J. M., \& Moreland, R. L. (1990). Progress in small group research. Annual Review of Psychology, 41, 585-634.

Levine, J. M., \& Moreland, R. L. (1991). Cognitive integration in work groups. In L. B. Resnick, J. M. Levine, \& S. D. Teasley (Eds.), Perspectives on socially shared cognition (pp. 257-279)

Leyva-Hernández, Sandra N.; Toledo-López, Arcelia; Hernández-Lara, Ana B. 2021. "Purchase Intention for Organic Food Products in Mexico: The Mediation of Consumer Desire" Foods 10, no. 2: 245.

Li, M., Huang, L., Tan, C.H. and Wei, K.K. (2013), "Helpfulness of online product reviews as seen by consumers: source and content features", International Journal of Electronic Commerce, Vol. 17 No. 4, pp. 101-136.

Lin H-F. Understanding behavioral intention to participate in virtual communities. CyberPsychology and Behavior 2006; 9:540-547.

Mahe, Y., 2015. History Of Jeans. https://www.fashionintime.org.

Copyright (C) GLOBAL ACADEMIC EXCELLENCE (M) SDN BHD - All rights reserved 
Volume 3 Issue 9 (September 2021) PP. 47-66 DOI 10.35631/AIJBES.39005

Malhotra, N. (2010). Marketing Research-An Applied Orientation Sixth Edition. Pearson/Prentice Hall.

Malik, M. S. I., \& Hussain, A. (2017). Helpfulness of product reviews as a function of discrete positive and negative emotions. Computers in Human Behavior, 73, 290-302.

March, J. G., \& Shapira, Z. (1987). Managerial perspectives on risk and risk taking. Management Science, 33(11), 1404- 1418.

Marks, L.J. and Olson, J.C. (1981), “Toward a cognitive structure conceptualization of product familiarity”, in Monroe, K.B. and Abor Içinde, A. (Eds), Advances in Consumer Research, Association for Consumer Research, Ann Arbor, MI, pp. 145-150.

Maryati, 2010. Statistika Ekonomi Dan Bisnis. 2nd ed. Yogyakarta: UPP, p.129. Paul, R., 2015. Denim. Woodhead Publishing.

McGowan, M., Shiu, E., \& Hassan, L. M. (2016). The influence of social identity on value perceptions and intention. Journal of Consumer Behaviour, 16(3), 242-253.

Meng, B., \& Choi, K. (2016). The role of authenticity in forming slow tourists' intentions: Developing an extended model of goal-directed behavior. Tourism Management, 57, 397-410.

Meng, B. and Han, H. (2016), "Effect of environmental perceptions on bicycle travelers' decision-making process: developing an extended model of goal-directed behavior", Asia Pacific Journal of Tourism Research, Vol. 21 No. 11, pp. 1-14.

M. Fishbein, I. Ajzen, Belief, Attitude, Intention, and Behavior: an Introduction to Theory and Research, Addison-Wesley, 1975.

Mitchell, A.A. and Dacin, P.A. (1996) 'The assessment of alternative measures of consumer expertise', Journal of Consumer Research, Vol. 23, No. 3, p.219.

Ordonez, L. D., Benson, L., \& Beach, L. R. (1999). Testing the compatibility test: how instructions, accountability, and anticipated regret affect prechoice screening of options. Organization Behavior and Human Decision Processes, 78(1), 63-80.

Ortony, A., Clore, G. L., \& Collins, A. (1988). The cognitive structure of emotions. Cambridge, UK: Cambridge University Press.

Oullett, J. A., \& Wood, W. (1998). Habit and intention in everyday life: The multiple processes by which past behavior predicts future behaviour. Psychological Bulletin, 124, 54-74.

P.A. Pavlou, M. Fygenson, "Understanding and Predicting Electronic Commerce Adoption: An Extension of the Theory of Planned Behavior", MIS Quarterly 30 (1) (2006) 115143

Pentina, I.; Prybutok, V.R.; Zhang, X. (2008). "The role of virtual community as shopping reference group," Journal of Electronic Commerce Research

Perugini, M., \& Bagozzi, R. P. (2001). The role of desires and anticipated emotions in goaldirected behaviours: Broadening and deepening the theory of planned behaviour. British Journal of Social Psychology, 40(1), 79-98.

Perugini, M., \& Bagozzi, R. P. (2004). The distinction between desires and intentions. European Journal of Social Psychology, 34(1), 69-84.

Petty RE, Cacioppo JT. 1986. Communication and Persuasion: Central and Peripheral Routes to Attitude Change: SpringerVerlag.

Postmes, T., \& Spears, R. (1998). Deindividuation and antinormative behavior: A metaanalysis. Psychological Bulletin, 123, 238-259

Postmes, T., Spears, R., \& Cihangir, S. (2001). Quality of decision making and group norms. Journal of Personality and Social Psychology, 80(6), 918-930.

Preacher, K. J., Rucker, D. D., \& Hayes, A. F. (2007). Addressing moderated mediation hypotheses: Theory, methods, and prescriptions. Multivariate Behavioral Research, 42(1), 185-227. https://doi.org/10.1080/00273170701341316

Copyright $\odot$ GLOBAL ACADEMIC EXCELLENCE (M) SDN BHD - All rights reserved 
Volume 3 Issue 9 (September 2021) PP. 47-66 DOI 10.35631/AIJBES.39005

Racherla, P., Mandviwalla, M. and Connolly, D., 2012. Factors affecting consumers' trust in online product reviews. Journal of Consumer Behaviour, 11(2), pp.94-104.

Ren, G., \& Hong, T. (2018). Examining the relationship between specific negative emotions and the perceived helpfulness of online reviews. Information Processing \& Management.

Rheingold, H., 1993. The Virtual Community. New York, NY: HarperPerennial.

Richard, R., van der Pligt, J., \& de Vries, N. K. (1996). Anticipated regret and time perspective: changing sexual risktaking behavior. Journal of Behavioral Decision Making, 9, 185199.

Ridings, C. and Gefen, D., 2006. Virtual Community Attraction: Why People Hang Out Online. Journal of Computer-Mediated Communication, 10(1).

Rizal, S., 2013. INDIGO, Komunitas Pencinta Denim Terbesar Se-Asia Tenggara. [online] Lpminstitut.com. Available at: <http://www.lpminstitut.com/2013/12/indigokomunitas-pencinta-denim.html > [Accessed 7 November 2020].

Salganik,Matthew J., Peter Sheridan Dodds and Duncan J.Watts(2006), "Experimental Study of Inequality and Unpredictability in an Artificial Cultural Market," Science, 311 (February), 854-6.

Salganik, Matthew J. and Duncan J. Watts (2008), "Leading the Herd Astray: An Experimental Study of Self-fulfilling Prophecies in an Artificial Cultural Market," Social Psychology Quarterly, 71 (December), 228-55.

Sarin, R. K. (1992). What now for generalized utility theory? In W. Edwards (Ed.), Utility Theories: Measurements and Applications (pp. 135-163). Boston: Kluwer Academic.

Saunders, M., Lewis, P. and Thornhill, A. (2007) Research Methods for Business Students. 4th Edition, Financial Times Prentice Hall, Edinburgh Gate, Harlow.

Schiffman, L.G. and Kanuk, L.L. (2007), Consumer Behavior, 9th ed., Prentice-Hall, NJ.

Sekaran, U. (2003) Research Methods for Business: A Skill-Building Approach. 4th Edition, John Wiley \& Sons, New York.

Sen, S., \& Lerman, D. (2007). Why are you telling me this? An examination into negative consumer reviews on the web. Journal of Interactive Marketing, 21(4), 76-94.

Shao, H. (2015). Online brand community usage: a motivation of consumption approach School of Graduate Studies Master of Science (Administration ). (August).

Shim, S., Eastlick, M. A., Lotz, S. L., \& Warrington, P. (2001). An Online Prepurchase Intentions Model: The Role of Intention to Search. Journal of Retailing, 397416.Simonson, I. (1992). The influence of anticipating regret and responsibility on purchase decisions. Journal of Consumer Research, 19, 105-118.

Smith, D., Menon, S., \& Sivakumar, K. (2005). Online peer and editorial recommendations, trust, and choice in virtual markets. Journal of Interactive Marketing, 19(3), 15-37.

Souiden, N., \& Diagne, M. (2009). Canadian and French Men's Consumption of Cosmetics: A Comparison of Their Attitudes and Motivations. Journal of Consumer Marketing

Stets, J. E., \& Burke, P. J. (2003). A sociological approach to self and identity. In: M. R. Leary \& J. P. Tangney (Eds), Handbook of self and identity (pp. 128-152). New York: The Guilford Press.

Suha, F.S., and Sharif, O.S. (2018). Self-identity and social identity as drivers of consumers' purchase intention towards luxury fashion goods and willingness to pay premium price. Asian Academy of Management Journal, 23(2), 161-184.

Suhari, Y., 2012. E-Commerce: Model Perilaku Konsumen. E-Commerce, .

Sukato, N., \& Elsey, B. (2009). A Model of Male Consumer Behavior in Buying Skin Care Products in Thailand. ABAC Journal Vol. 29, No. 1, 39-52. 
Volume 3 Issue 9 (September 2021) PP. 47-66 DOI 10.35631/AIJBES.39005

Tajeddini, K., \& Nick Davoodi, J. N. (2014). Cosmetic buying behavior: examining the effective factors. Journal of Global Scholars of Marketing Science: BridgingAsia and the World, 395-410.

Taylor, S., \& Todd, P. (1995). Understanding Information Technology Usage: A Test of Competing Models. Information Systems Research, 144-176.

Turner, J. C., Brown, R. J., \& Tajfel, H. (1979). Social comparison and group interest in ingroup favouritism. European Journal of Social Psychology, 9(2), 187-204.

Walther JB, Liang Y ( Jake), Ganster T, et al. Online reviews, helpfulness ratings, and consumer attitudes: an extension of congruity theory to multiple sources in web 2.0. Journal of Computer-Mediated Communication 2012; 18:97-112.

Wang, S., Cunningham, N. R., \& Eastin, M. S. (2015). The Impact of eWOM Message Characteristics on the Perceived Effectiveness of Online Consumer Reviews. Journal of Interactive Advertising, 15(2), 151-159.

Weiner, B. (1992). Human Motivation: Metaphors, Theories and Research. Newbury Park, CA: Sage.

Wong, K. K. K.-K. (2013). 28/05 - Partial Least Squares Structural Equation Modeling (PLSSEM) Techniques Using SmartPLS. Marketing Bulletin, 24(1), 1-32.

Wong, ML \& Leung, KS 2002, Data mining using grammar based genetic programming and applications. Genetic Programming, vol. 3, Kluwer Academic, Boston. https://doi.org/10.1007/b116131

Zarouali, B., Van den Broeck, E., Walrave, M., \& Poels, K. (2018). Predicting Consumer Responses to a Chatbot on Facebook. Cyberpsychology, Behavior, and Social Networking, 21(8), 491-497.

Zeelenberg, M. (1999a). Anticipated regret, expected feedback, and behavioral decision making. Journal of Behavioral Decision Making, 12, 93-106.

Zeelenberg, M. (1999b). The use of crying over spilled milk: a note on the rationality and functionality of regret. Philosophical Psychology, 12(3), 325-340.

Zheng, Y., \& Chi, T. (2014). Factors influencing purchase intention towards environmentally friendly apparel: an empirical study of US consumers. International Journal of Fashion Design, Technology and Education, 8(2), 68-77.

Zhou, Lina \& Dai, Liwei \& Zhang, Dongsong. (2007). Online shopping acceptance model - A critical survey of consumer factors in online shopping. Journal of Electronic Commerce Research. 8.

Zhu, F. and Zhang, X. (2010), "Impact of online consumer reviews on sales: the moderating role of product and consumer characteristics", Journal of Marketing, Vol. 74 No. 2, pp. 133-148. 